\title{
PENGUATAN PENDIDIKAN MORAL SISWA MELALUI PELAJARAN PENDIDIKAN AGAMA ISLAM DAN EKSTRAKURIKULER DI MTs. NU WALISONGO SIDOARJO
}

\author{
Arina Salamah \\ Mahasiswa Pascasarjana UIN Sunan Ampel Surabaya \\ Email: arinasalamah@gmail.com \\ Dikirim: 13 Juli 2020 | Direvisi: 25 Juli 2020 | Dipublikasikan: 31 Juli 2020
}

\begin{abstract}
Moral Education is education to make human children moral or human. This means that moral education is education that does not teach about academics, but non-academics specifically about attitudes and how good everyday behavior. This paper is the result of field research entitled "strengthening the moral education of students in following the eyes of Islamic and extracurricular learning in mts nu 'walisongo sidoarjo". issues discussed include how morale students in MTs. NU Walisongo Sidoarjo ?, How to strengthen moral education of students in MTs. NU Walisongo Sidoarjo? And What are the supporting and inhibiting factors of the Student Morale Education Strengthening Program at MTs. NU Walisongo Sidoarjo? To answer the above problems the authors use the case study method combined with field studies. This research uses qualitative research. Researchers use Emile Durkheim's theory as quoted by George Ritzer and Douglas J. Goodman defines moral education is education that will be carried to the end of life. Education will determine when he becomes a useful human being, and will take him to heaven or hell later. The results of this study concluded that, the strengthening of students' moral education was formed through positive programs that were quite simple and not burdensome for students and teachers, where those programs were able to form good character and achievements for students of MTs. Nu Sidoarjo.

Keywords : Religious education; moral education; extracurricular at school achievement.
\end{abstract}

\section{Pendahuluan}

Pendidikan saat ini menarik perhatian serius oleh masyarakat luas, disaat moralitas dipinggirkan dari sistem berperilaku dan bersikap di tengah masyarakat. Secara de jure, pendidikan meningkatkan kualitas berbagai dimensi kehidupan manusia. secara de facto, pendidikan yang diusung seringkali menjadikan manusia kehilangan kemanusiannya. Aksi kekerasan, korupsi, dan sederet gambaran dekadensi moral menghadirkan kerinduan untuk mendesain ulang sistem pendidikan yang berbasis moralitas. Kehidupan dan pendidikan bagaikan sebuah skema listrik paralel. Keduanya saling terkait 

satu dengan yang lain. Oleh karena itu, jika masyarakat menghendaki kehidupan yang berkualitas, isi dan proses pendidikan harus diarahkan pada pemenuhan kebutuhan tersebut. ${ }^{1}$

Penguatan Pendidikan moral dalam konteks era saat ini sangat cocok untuk mengatasi krisis moral yang sangat sering terjadi negara ini, khususnya Indonesia. Diantara krisis moral yang sering banyak terjadi di kalangan anak muda yaitu pergaulan bebas, maraknya angka kekerasan pada remaja, kejahatan terhadap temannya, dan sekarang yang sedang banyak dibicarakan tentang fenomena siswa yang bersikap kriminal kepada gurunya sendiri, dan lain sebagainya. Dari semua contoh tersebut saat ini belum teratasi dengan tuntas, maka dari itu pendidikan moral itu sangat penting ditanamkan dari dini. Adapun tempat kejadiannya bisa terjadi di kota-kota besar, kota kabupaten, dan bahkan di pelosok-pelosok daerah termasuk di lingkungan lembaga sekolah. Jika hal ini berlangsung terus dan tidak dapat dikendalikan secara tepat maka akan berdampak negatif terhadap merosotnya lembaga pendidikan sebagai tempat untuk membina dan mendidik generasi muda sebagai penerus bangsa yang berakhlak mulia.

Dari fenomena diatas itu adalah sebagian contoh maraknya kemerosotan akhlak yang terjadi di berbagai tempat. Ini bisa diamati berkembangnya perilaku menyimpang. Bahkan dunia pendidikan tidak luput dari fenomena kemerosotan akhlak. Sejumlah aksi tawuran, kekerasan, penyalahgunaan narkoba terbukti melibatkan kaum pelajar, baik itu dari kalangan siswa maupun mahasiswa.

Dalam hal ini KPAI (Komisi Perlindungan Anak Indonesia) mencatat ada 6000 anak berhadapan dengan hukum, dan mendekam di dalam penjara. Baik itu penjara anak, dewasa ataupun tahanan lainnya. diantaranya itu ada siswa sekolah.

Merosot moralnya remaja khususnya pada anak-anak yang sekolah di lembaga pendidikan formal menunjukkan masih belum terbentuk keterpaduan dalam pengelolaan sistem penanaman maupun pembinaan nilai-nilai moral di sekolah, pengelolaan sistem penanaman maupun pembinaan nilai-nilai moral yang dimaksud adanya keterkaitan antara kegiatan intrakurikuler dan kegiatan ekstrakurikuler dalam suatu sistem pola penanaman nilai-nilai moral pada siswa di sekolah.

UUD Tahun 1945 No 23 tahun 2002 dijelaskan “Anak yang disebutkan dalam pembahasan ini adalah seorang yang belum berusia 18 tahun , anak ini masih termasuk dalam kandungan. ${ }^{2}$ Dalam UUD 1945 Pasal 2b ayat 2 menjelaskan bahwa anak itu berhak untuk hidup, tumbuh, berkembang dan berpartisipasi wajar yang sesuai dengan harkat dan martabat manusia. Serta mendapatkan perlindungan dari kekerasan dan diskriminasi. ${ }^{3}$

\footnotetext{
${ }^{1}$ Aswan Sahlan \& Angga Teguh Prasetyo, Desain Pembelajaran Berbasis Pendidikan Karakter (Jogjakarta: Ar-Ruzz Media, 2012), 13.

${ }^{2}$ Komisi Perlindungan Anak Indonesia, Panduan Sekolah dan Madrasah ramah anak (Jakarta:Erlangga,2016),16.

${ }^{3}$ Syaiful Sagala,Etika dan moralitas pendidikan (Jakarta: Kencana Grup, 2013), 221.
} 
Ada beberapa yang memang harus guru fahami tentang karakteristik siswanya, sehingga penyampaian materi yang diajarkan itu sampai dan dimengerti siswa itu. Meskipun tidak semua siswa mempunya karakteristik yang tidak sama, Tetapi guru juga harus bisa sekreatif mungkin atau menyiasati cara mengajarnya yang pas untuk satu kelas. Sehingga tidak ada satu kesalahan yang membuat moral anak itu berkurang atau malah nanti sangat fatal. Seperti fenomena di Sampang siswa membunuh gurunya sendiri. ${ }^{4}$

Sikap guru terhadap siswa adalah faktor penting untuk mencapai keberhasilan. Seperti yang dijelaskan Johnson bila guru yakin bahwa siswanya akan berhasil maka siswanya itu akan berhasil. Oleh karena itu guru membantu siswanya menyakini bahwa keberhasilan adalah sesuatu yang mungkin untuk siswa itu sendiri. Guru bagi siswa adalah sebagai pengganti orang tua disekolah untuk mendidik dan membantu pertumbuhan perkembangan sang anak dalam melakukan pembelajaran di sekolah. Guru disekolah perannya sangat besar yaitu untuk membentuk karakter dan watak siswanya. ${ }^{5}$

Pendidikan moral memang bukanlah persoalan baru. Banyak ahli pendidikan telah merumuskan konsep pendidikan dan menjadikan moral sebagai bagian yang tidak terpisahkan dari sistem pendidikan. sering dikatakan bahwa pembentukan moral yang baik merupakan tujuan umum dan tujuan akhir dari keseluruhan proses pendidikan.

Terkait itu Al Ghazali sebagaimana yang dikutip Muhammad al-Arabi bahwa pada dasarnya seorang anak memiliki potensi yang sama untuk menjadi pribadi yang baik atau sebaliknya menjadi pribadi yang buruk. Hal ini juga ditegaskan dalam firman Allah dalam surat Al-Shams ayat 7-10 berikut ini:

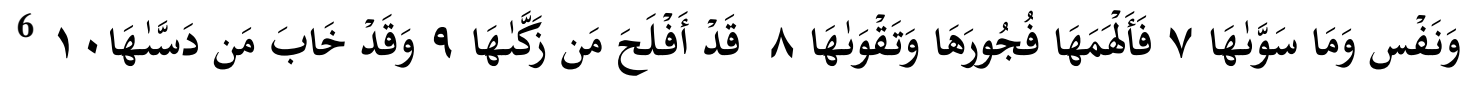

Artinya : Dan jiwa serta penyempurnaannya (ciptaannya). maka Allah mengilhamkan kepada jiwa itu (jalan) kefasikan dan ketakwaannya. sesungguhnya beruntunglah orang yang mensucikan jiwa itu. dan sesungguhnya merugilah orang yang mengotorinya.

Ayat tersebut menjelaskan bahwa setiap jiwa memiliki potensi menjadi hamba yang taat dan baik atau malah sebaliknya menjadi buruk. Pandangan tentang moral memiliki kaitan erat dengan Islam, karena salah satu pesan penting dalam ajarannya diantaranya ada pembentukan moral atau akhlak yang baik di dalam kehidupan sehari-hari dan berhubungan dengan masyarakat .

\footnotetext{
4 Ibid, 224.

${ }^{5}$ Ibid, 222

6 Al-Qur'an (91): 7-10

${ }^{7}$ Kementerian Agama Republik Indonesia, al-Qur'an dan TerJemabnya (Jakarta: al-Mizan, 2011), 259.
} 
Dalam sejarah yang dimiliki umat Islam, bahwa ada di dalam hadis yang menjelaskan bahwa Nabi Muhammad di dalam misi utamanya untuk mendidik manusia dan untuk menyempurnakan akhlak, untuk mengajak semua umatnya untuk berperilaku yang sopan, yang baik, dan untuk menanamkan moral yang baik terhadap sesama. ${ }^{8}$

MTs. NU Walisongo Sidoarjo sebagai salah satu lembaga yang membidangi pendidikan di bawah naungan BPPMNU (Badan Pelaksana Pendidikan Ma'arif NU), inilah sebabnya MTs NU Walisongo Sidoarjo lebih dikenal oleh masyarakat dengan sebutan MTs NU Walisongo. MTs ini berdiri sejak tahun 1978 M, bermula dari perwujudan Madrasah Muallimah dan Mu'allimin Nahdlatul Ulama'. Sejak berdirinya Madrasah ini, berstatus terdaftar, kemudian diakui, dan pada 2004 Madrasah ini mendapatkan status terakreditasi A hingga sekarang.

\section{Kajian Teori}

\section{Pendidikan Moral Pembentuk Karakter Siswa}

Pendidikan menurut kamus besar bahasa Indonesia (KBBI) merupakan proses pengubahan sikap dan tata laku seseorang atau kelompok orang dalam usaha mendewasakan manusia melalui upaya pengajaran dan pelatihan. Bisa juga diartikan bahwa pendidikan adalah suatu proses perubahan sikap dan perilaku seseorang atau kelompok sebagai usaha pendewasaan melalui pengajaran dan pelatihan. Dan dapat diartikan sebagai salah satu proses memanusiakan manusia melalui usaha sadar terencana. ${ }^{9}$

Moral berasal dari bahasa latin yaitu mos, mos adalah bentuk kata tunggal. sedangkan bentuk jamaknya yaitu morse yang berarti itu adalah kebiasaan, susila. Kebiasaan adalah tindakan manusia yang dilakukan secara berulang-ulang dalam hal yang sama yang baik ataupun buruk dalam suatu masyarakat. jika kebiasaan tertentu itu diterima oleh masyarakat dan dilakukan secara berulangulang maka itu akan menjadi kebiasaan yang baik.kebiasaan dalam arti lain sesuatu yang biasa dikerjakan.

Moral adalah hal mutlak yang harus dimiliki tiap individu. Moral juga bisa dikatakan akhlak atau tingkah laku manusia. Kata moral sama juga dengan istilah etika yang berasal dari bahasa yunani yaitu Ethos, suatu kebiasaan adat istiadat. Dari pengertian pendidikan moral itu juga sama menurut Karl Barth.

\footnotetext{
8 Abdul Majid, Pendidikan Karakter Prespektif Islam (Bandung:PT Rosda Karya, 2011), 2. Menyempurnakan akhak personal maka akan terbentuklah moral masyarakat. Baca Mustari Mustafa, Konstruksi filsafat Nilai antara Normativitas dan Realitas (Makassar: Alauddin University Press, 2011), 163.

${ }^{9}$ Damsar, Pengantar Sosiologi Pendidikan (Jakarta: Kencana, 2011), 8.
} 
Pendidikan moral diberikan di berbagai macam lembaga pendidikan, dari tingkat PAUD sampai Perguruan Tinggi. Pendidikan moral tentang sikap dan kepribadian, sehingga di dalam pembelajarannya tidak hanya terbatas pada pengembangan kemampuan intelektualnya saja tetapi lebih kepada pengembangan karakter, sikap, dan perilaku peserta didik.

Menurut istilah etika adalah ajaran tentang baik dan buruk, yang diterima umum tentang sikap dan perbuatan. Dan pada hakikatnya moral juga bisa dikatakan ukuran-ukuran yang telah diterima oleh suatu komunitas, sedangkan etika lebih dikaitkan dengan prinsip-prinsip yang dilakukan oleh suatu profesi. ${ }^{10}$

Terminologi pendidikan moral akhir-akhir ini sering digunakan untuk menjelaskan penyelidikan isu-isu etika di dalam kelas dan sekolah. Pengajaran etika di dalam pendidikan moral lebih cenderung pada nilai-nilai yang salah, sedangkan penerapan nilai-nilai itu di dalam keluarga, masyarakat sudah tidak mendapatkan porsi yang memadai.

Bisa dikatakan itu sangat normatif dan kurang bersinggungan dengan ranah afektif dan psikomotorik siswa. Moral Islam seperti yang dikemukakan Abu A'la al-Maududi di dalam buku Ethical View Point of Islam memberikan garis tegas antara moral sekuler dengan moral Islam. Moral sekuler itu bersumber pada pikiran dan prasangka manusia yang beraneka ragam, sedangkan moral Islam bersumber pada bimbingan dan petunjuk Allah di dalam al-Quran.

Pada uraian sebelumnya, moral dapat dipersamakan dengan istilah etik, kesusilaan dan budi pekerti. Moral merupakan nilai tentang baik-buruk kelakuan manusia. Oleh karena itu moral berkaitan dengan nilai terutama nilai afektif. Dengan demikian pendidikan moral dapat pula dipersamakan dengan istilah pendidikan etik, pendidikan budi pekerti, pendidikan nilai (value education) atau pendidikan afektif.

Ada pula dengan memakai istilah pendidikan watak dan pendidikan akhlak Dalam hal ini istilah-istilah tersebut dapat saling menggantikan. Jadi istilah ini tidak bisa lepas dari pengertian moral, nilai, budi pekerti , watak, akhlak atau afektif itu sendiri. ${ }^{11}$

Terkait dengan moralitas atau akhlak manusia ini, al-Ghazali membuat pembedaan dengan menempatkan manusia pada empat tingkatan. Pertama, terdiri dari orang-orang yang lengah, yang tidak dapat membedakan kebenaran dengan yang palsu, atau antara yang baik dengan yang buruk.

Nafsu jasmani kelompok ini bertambah kuat, karena tidak memperturutkannya. Kedua, terdiri dari orang yang tahu betul tentang keburukan dari tingkah laku yang buruk, tetapi tidak menjauhkan diri dari perbuatan itu. Mereka tidak dapat meninggalkan perbuatan itu disebabkan adanya kenikmatan yang dirasakan dari perbuatannya itu.

\footnotetext{
${ }^{10}$ Muhammad Takdir Illahi, Revitalisasi Pendidikan Berbasis Moral (Yogyakarta: AR RUZZ Media, 2012), 181.

${ }^{11}$ Naskah akademik. 2001 Buram -VI. Kurikulum Pendidikan Budi Pekerti. Puskur Depdiknas
} 
Ketiga, orang-orang yang merasa bahwa perbuatan buruk yang dilakukannya adalah sebagai perbuatan yang benar dan baik. Pembenaran yang demikian dapat berasal dari adanya kesepakatan kolektif yang berupa adat kebiasaan suatu masyarakat. Dengan demikian orang-orang ini melakukan perbuatan tercelanya dengan leluasa dan tanpa merasa berdosa. Keempat, orang-orang yang dengan sengaja melakukan perbuatan buruk atas dasar keyakinannya.

\section{Metode Penelitian}

Penelitian ini menggunakan metode gabungan studi kasus dan penelitian lapangan. Penggalian data menggunakan wawancara, dokumentasi dan observasi. Analisis dengan reduksi data, penyajian data dan verifikasi data.

\section{Paparan data Penelitian}

\section{Penguatan Pendidikan Moral Siswa di MTs. NU Walisongo Sidoarjo}

Citra adalah gambaran positif ataupun negatif pada suatu obyek tertentu. Dalam hal ini peneliti akan membahas mengenai citra sekolah. Sekolah yang mempunyai citra positif biasanya lebih menarik bagi orang tua siswa untuk memasukkan anaknya di sekolah tersebut. Citra yang baik harus dibangun oleh sebuah lembaga, karena merupakan cikal bakal mempertahankan eksistensi lembaga tersebut.

Dalam penelitian ini, peneliti menemukan bahwa citra MTs NU menurut pandangan publik adalah sekolahnya bagus, pelajaran agamanya juga banyak. Seperti yang disampaikan dalam wawancara berikut ini:

"Sekolahnya bagus dan pelajaran agamanya juga banyak"12

Citra MTs NU Sidoarjo juga terbentuk melalui program-program positif dimana program-program tersebut ternyata mampu membentuk karater bagus bagi siswa-siswa $\mathrm{Mts} \mathrm{Nu}$, program yang disusun oleh Waka Humas dan prestasi-prestasi yang dihasilkan oleh siswa siswinya yang selalu mengalami perkembangan sangat pesat, baik di bidang akademik maupun non akademik. Program-program tersebut diantaranya: ${ }^{13}$

Tabel 1

Program Pengembangan Diri MTs. NU Sidoarjo

\begin{tabular}{|l|l|l|}
\hline \multicolumn{3}{|c|}{ Program pencetak pribadi Tangguh dan berkaraker } \\
\hline Teater & Pramuka & PMR \\
\hline Banjari / Nasyid & Drum band & Marcing band \\
\hline Paskibraka & Qiroah & Pencak silat \\
\hline Futsal & Bulu tangkis & Volley \\
\hline Jurnalistik & Matematika & Bahasa Inggris \\
\hline Sholat Berjamaah & Hafalan juz Amma & Istighotsah Bersama guru dan siswa \\
\hline Ziarah wali songo & Budaya wajib salaman & Patnership \& leadership \\
\hline
\end{tabular}

12 Tomima, Wali Siswa MTs. NU Sidoarjo, Wawancara, Senin 7 Mei 2018.

13 Wawancara dengan Guru MTs. NU Walisongo Sidoarjo, Desember 2019 
Pada saat observasi peneliti menjumpai seluruh siswa berjalan menuju masjid yang ada di dekat sekolah untuk melaksanakan sholat dhuhur berjamaah bersama beberapa guru. Kegiatan tersebut dilaksanakan di masjid yang ada di luar sekolah dengan harapan masyarakat yang melihat dapat menimbulkan kesan yang positif bagi MTs NU.

Prestasi-prestasi MTs NU juga ikut andil dalam membentuk citra positif dalam pandangan publik. Baik prestasi akademik maupun non akademik. Diantara prestasi yang dicapai yaitu:

Prestasi non akademik dikembangkan oleh sekolah melalui ekstrakurikuler. Seperti yang disampaikan oleh kepala madrasah bahwa MTs. NU berani bersaing dalam bidang ekstrakurikuler. Hal tersebut sebagaimana disampaikan dalam wawancara dengan peneliti:

"Ya jaga image dan tidak mau kalah dengan sekolah lain. Selalu siap bersaing. Saya kembangkan kemampuan anak-anak dalam kegiatan ektrakurikuler, dan itu berhasil bisa dilihat tropy-tropy kita." 14

Peneliti juga mendapatkan informasi dari siswa, bahwa mereka sekolah di MTs NU salah satunya karena melihat MTs NU yang mempunyai banyak prestasi. berikut kutipan wawancaranya:

"karena saya melihat MTs NU itu banyak kejuaraannya dan kuat agamanya"15

Dengan demikian, dapat diketahui bahwa citra MTs NU dalam pandangan publik baik dan banyak diminati publik untuk masuk ke MTs NU Walisongo Sidoarjo.

Berikut ini deskripsikan hasil wawancara terkait bagaimana penguatan pendidikan moral yang diimplementasi sikan di MTs. NU Walisong Sidoarjo.

Tabel. 2

Deskripsi Wawancara Terkait Penguatan Pendidikan Moral di MTs. NU Sidoarjo

Bagaimana penguatan pendidikan moral siswa yang ada di mts nu walisongo sidoarjo?
Melalui pembiasaan dan suri tauladan dari seluruh stake holder Madrasah, sebagai contoh seluruh masyarakat madrasah kalau ketemu harus bersalaman, saling menghormati, sholat berjamaah

\footnotetext{
14 Wawancara dengan dewan guru MTs. NU Walisongo Sidoarjo, Desember 2019

15 Wawancara dengan Guru MTs. NU Walisongo Sidoarjo, Desember 2019
} 


\begin{tabular}{|c|c|}
\hline $\begin{array}{l}\text { Berapa siswa yang belajar tentang pendidikan } \\
\text { moral disekolah? }\end{array}$ & $\begin{array}{l}\text { Seluruh siswa diajarkan oleh dewan guru tentang } \\
\text { Pendidikan moral di sekola }\end{array}$ \\
\hline $\begin{array}{l}\text { Seberapa tingkat keberhasilan guru mengajar } \\
\text { pendidikan moral terhadap siswa? Dan dalam } \\
\text { bentuk apa tingkat keberhasillannya? }\end{array}$ & $\begin{array}{l}\text { cukup berhasil hal ini bisa dilihat dari rekord } \\
\text { BP/BK tentang perilaku siswa dari mulai siswa } \\
\text { masuk sampai keluar madrasah rata rata kasus } \\
\text { perilaku yang ditangani BP/BK di kela } 7 \text { dan } 8 \\
\text { cukup banyak dan akan menurun di kelas } 9 \text { (ini } \\
\text { adalah salah satu indikator) }\end{array}$ \\
\hline $\begin{array}{l}\text { Apa ada keterkaitan penerapan pendidikan } \\
\text { moral siswa dengan mata pelajaran atau } \\
\text { ekstrakurikuler? }\end{array}$ & $\begin{array}{l}\text { Hubungannya sangat terkait sekali } \\
\text { hal ini sangat membantu proses pembelajaran } \\
\text { karena suasana proses pembelajaran akan lebih } \\
\text { semangat dan kelas jadi lebih kondusif bagi } \\
\text { kegiatan ekstra menjadi luar biasa lebih disiplin } \\
\text { semangat tertib sehingga banyak prestasi yang } \\
\text { diraih }\end{array}$ \\
\hline $\begin{array}{l}\text { Mata pelajaran apakah atau ektrakurikuler yang } \\
\text { ada di sekolah dengan penguatan pendidikan } \\
\text { moral tersebut? }\end{array}$ & $\begin{array}{l}\text { Hampir semua mata pelajaran khususnya } \\
\text { pelajaran agama dan semua kegiatan ekstra } \\
\text { berkaitan dengan moral seperti Pramuka, } \\
\text { Paskib, PMR, teater, banjari dll }\end{array}$ \\
\hline $\begin{array}{l}\text { Apa dampak dari penguatan pendidikan moral } \\
\text { siswa yang ada di mts nuwalisongo sidoarjo? }\end{array}$ & $\begin{array}{l}\text { Madrasah suasananya akan lebih nyaman } \\
\text { kondusif tertib karena akan selalu saling } \\
\text { menghargai satu sama lain }\end{array}$ \\
\hline $\begin{array}{l}\text { Apa faktor pendukung dan penghambat } \\
\text { program penguatan pendidikan moral siswa di } \\
\text { mtsnu walisongo sidoarjo? }\end{array}$ & $\begin{array}{l}\text { faktor pendukung semua stake holder madrasah } \\
\text { mendukung terhadap penguatan pendidikan } \\
\text { moral sebagai menu utama pendidikan untuk } \\
\text { mencapai keberhasilan dalam hidup } \\
\text { faktor penghalang antara lain tidak semua wali } \\
\text { siswa berpandangan sama dengan madrasah } \\
\text { sehingga perlu adanya pertemuan dengan wali } \\
\text { siswa untuk menyampaikan dari program } \\
\text { sekolah tentang pentingnya pendidikan moral, } \\
\text { bisa melalui pertemuan seluruh wali siswa, } \\
\text { ataupun melalui komunikasi dengan wali kelas } \\
\text { dan BP/BK }\end{array}$ \\
\hline $\begin{array}{l}\text { Bagaimana moral siswa di mtsnu walisongo } \\
\text { sidoarjo }\end{array}$ & $\begin{array}{l}\text { Sejak penerapan Pendidikan moral di madrasah, } \\
\text { siswa lebih mampu mengaktualisasikan proses } \\
\text { disiplin di sekolah maupun diluar sekolah, dan } \\
\text { ini berpengaruh kepada prestasi siswa, baik } \\
\text { prestasi akademik maupun prestasi non } \\
\text { akademik. }\end{array}$ \\
\hline
\end{tabular}

\section{Faktor Pendukung dan Penghambat Program Penguatan Pendidikan Moral}

Perlu diingat bahwa untuk mengubah ataupun membentuk sistem nilai pada diri anak dibutuhkan proses, tidak bisa secara instan dibentuk karakter tersebut, oleh sebab itu untuk semua pihak yang ikut membantu untuk terciptanya moral yang baik memang dibutuhkan usaha yang keras dan kesabaran.

Harapannya ketika penanaman karakter dikatakan berhasil pada remaja maka dapat membangun tanah air menjadi maju dan tetap berpegang teguh pada nilai agama, moral, dan aturan 
kehidupan bermasyarakat dan bernegara melalui cerminan etika, moral, budi pekerti, dan ditandai dengan samangat, tekad, dan energi yang kuat, dengan pikiran positif dari sikap yang optimis.

Sepertihalnya yang sudah diterapkan di MTs. NU Walisongo, bahwasanya Pendidikan moral dianggap sebagai pintu utama mencetak keberhasilan belajar mengajar sampai pada output menciptakan lulusan-lulusan yang mapan baik dalam segi IPTEK maupun IMTAQ. Inilah yang melatarbelakangi bahwa tidak akan tercipta Visi besar sekolah tanpa adanya bantuan dan bahumembahu semua steakholder sekolah, wali santri, murid dan tenaga penunjang lainnya.

Hal tersebut dijelaskan oleh mayoritas dewan guru di MTs. NU Sidoarjo terkat faktor pendukung dan penghambat implementasi penguatan pendidikan moral, berikut kutipan wawancaranya:

"Faktor pendukung semua stake holder madrasah mendukung terhadap penguatan pendidikan moral sebagai menu utama pendidikan untuk mencapai keberhasilan dalam hidup. Faktor penghalang antara lain tidak semua wali siswa berpandangan sama dengan madrasah sehingga perlu adanya pertemuan dengan wali siswa untuk menyampaikan dari program sekolah tentang pentingnya pendidikan moral bisa melalui pertemuan seluruh wali siswa, ataupun melalui komunikasi dengan wali kelas dan BP/BK."

\section{Reinternalisasi pendidikan Moral Siswa Melalui Pelajaran Pendidikan Agama Islam dan}

\section{Ekstrakulikuler : Sebuah Analisis}

Pendidikan adalah bagian terpenting dalam kehidupan berbangsa dan bernegara. Sebuah bangsa dapat dikatakan maju apabila pendidikan di negara tersebut maju dan dapat mengelola SDM dan SDA dengan baik untuk kesejahteraan warganya. Untuk itu, berbagai upaya telah dilakukan bersama oleh berbagai pihak demi memajukan pendidikan Indonesia.

Namun demikian, membekali generasi masa depan dengan ilmu pengetahuan dan teknologi (IPTEK) saja tidaklah memadai guna melanjutkan bahkan untuk memajukan kehidupan bangsa. Mereka perlu mendapatkan pendidikan moral yang membentuk generasi penerus bangsa sebagai pribadi yang berakhlak mulia, jujur dan bertanggung jawab.

Pendidikan moral inilah salah satu modal untuk memperbaiki kondisi bangsa. Moral merupakan pengetahuan yang menyangkut budi pekerti manusia yang beradab. Demikian pula bisa dipakai sebagai ajaran tentang baik dan buruk perbuatan serta kelakuan (akhlak). Moralisasi adalah pandangan atau ajaran tentang perbuatan dan perilaku yang baik sedangkan demoralisasi adalah kerusakan moral. Sehingga moral adalah aturan yang meliputi semua norma perbuatan untuk bertingkah laku yang baik

16 Wawancara dengan Guru MTs. NU Walisongo Sidoarjo, Desember 2019 


\section{Arina Salamah}

Namun amat disayangkan, Pendidikan moral masih terbilang rendah. Seperti kita ketahui dari media massa begitu banyaknya kasus yang terjadi di kalangan sekitar kita. Contohnya tawuran yang marak terjadi dikalangan pelajar. Selain itu bukti lain adalah para koruptor, mereka adalah orang-orang yang berpendidikan tinggi namun tidak disertai oleh moral yang baik. Jadi, jika seseorang cerdas, akan tetapi moralnya tidak baik. Maka sama saja sia-sia. Hal inilah yang harus diantisipasi.

Memang saat ini pendidikan moral seakan dinomor dua-kan. Kita sebagai calon penerus bangsa sudah seharusnya memahami hakikat bahwa moral yang baik dan disertai dengan kecerdasan akademik maupun non akademik akan membawa kita dalam kesuksesan yang sesungguhnya.

Suyanto (2010) menyatakan bahwa dengan pendidikan moral yang diterapkan secara sistematis dan berkelanjutan, seorang anak akan menjadi cerdas emosinya. Kecerdasan emosi ini adalah bekal penting dalam mempersiapkan anak menyongsong masa depan, karena seseorang akan lebih mudah dan berhasil menghadapi segala macam tantangan kehidupan, termasuk tantangan untuk berhasil.

\section{Kesimpulan}

Pendidikan adalah bagian terpenting dalam kehidupan berbangsa dan bernegara, dalam membangun bangsa dan negara melalui Pendidikan tidak cukup hanya sekedar mengadakan proses belajar mengajar biasa, tetapi siswa perlu mendapatkan pendidikan moral yang mampu membentuk generasi penerus bangsa sebagai pribadi yang berakhlak mulia, jujur dan bertanggung jawab, Adapun Langkah tersebut bisa dicapai melalui Pendidikan moral disekolah, Sebagaimana yang bisa disimpulkan oleh penulis terhadap penelitian Penguatan Pendidikan Moral Siswa melalui pelajaran pendidikan agama islam dan ekstrakulikuler di MTs. NU Walisongo Sidoarjo;

Penguatan pendidikan moral siswa MTs. NU Sidoarjo juga terbentuk melalui programprogram positif dimana program-program tersebut ternyata mampu membentuk karater bagus bagi siswa-siswa MTs NU, terbukti dengan penerapan penguatan melalui Pendidikan gama islam seperti pembiasaan suri tauladan yang baik dari seluruh stakeholder madrasah, seperti harus bersalaman jika bertemu teman, guru dan masyarakat, Pendidikan saling menghormati yang lebih tua dan menyayangi yang lebih muda, sholat berjamaah di sekolah, rutinitas banjari, pengajaran leadhership melalui kegiatan palang merah remaja, kepramukaan dll, ternyata berdampak luar biasa terhadap peningkatan hasil nilai siswa baik dari segi akademik dan non akademik.

Faktor pendukung semua stake holder madrasah mendukung penuh terhadap penguatan pendidikan moral sebagai menu utama pendidikan untuk mencapai keberhasilan dalam hidup. Adapun Faktor penghalang antara lain tidak semua wali siswa berpandangan sama dengan 
madrasah sehingga perlu adanya pertemuan dengan wali siswa untuk menyampaikan dari program sekolah tentang pentingnya pendidikan moral bisa melalui pertemuan seluruh wali siswa, ataupun melalui komunikasi dengan wali kelas dan BP/BK.

\section{Daftar Kepustakaan}

Damsar, Pengantar Sosiologi Pendidikan. Jakarta: Kencana, 2011.

Illahi, Muhammad Takdir. Revitalisasi Pendidikan Berbasis Moral. Yogyakarta: AR RUZZ Media, 2012. Kementerian Agama Republik Indonesia, al-Qur'an dan TerJemahnya. Jakarta: al-Mizan, 2011.

Komisi Perlindungan Anak Indonesia, Panduan Sekolah dan Madrasah Ramah Anak. Jakarta: Erlangga, 2016.

Majid, Abdul. Pendidikan Karakter Prespektif Islam. Bandung: PT Rosda Karya, 2011.

Mustafa, Mustari. Konstruksi filsafat Nilai antara Normativitas dan Realitas Makassar: Alauddin University Press, 2011.

Sagala, Syaiful. Etika dan moralitas pendidikan. Jakarta: Kencana Grup, 2013.

Sahlan, Aswan \& Angga Teguh Prasetyo, Desain Pembelajaran Berbasis Pendidikan Karakter. Jogjakarta: Ar-Ruzz Media, 2012.

Naskah akademik. 2001 Buram -VI. Kurikulum Pendidikan Budi Pekerti. Puskur Depdiknas

Tomima, Wali Siswa MTs. NU Sidoarjo, Wawancara, Senin 7 Mei 2018.

Wawancara dengan Guru MTs. NU Walisongo Sidoarjo, Desember 2019. 